IZA DP No. 9355

Sex, Race, and Job Satisfaction among Highly Educated Workers

Joni Hersch

Jean Xiao

September 2015 


\title{
Sex, Race, and Job Satisfaction among Highly Educated Workers
}

\author{
Joni Hersch \\ Vanderbilt University \\ and IZA \\ Jean Xiao \\ Vanderbilt University
}

\section{Discussion Paper No. 9355 \\ September 2015}

\author{
IZA \\ P.O. Box 7240 \\ 53072 Bonn \\ Germany \\ Phone: +49-228-3894-0 \\ Fax: +49-228-3894-180 \\ E-mail: iza@iza.org
}

\begin{abstract}
Any opinions expressed here are those of the author(s) and not those of IZA. Research published in this series may include views on policy, but the institute itself takes no institutional policy positions. The IZA research network is committed to the IZA Guiding Principles of Research Integrity.

The Institute for the Study of Labor (IZA) in Bonn is a local and virtual international research center and a place of communication between science, politics and business. IZA is an independent nonprofit organization supported by Deutsche Post Foundation. The center is associated with the University of Bonn and offers a stimulating research environment through its international network, workshops and conferences, data service, project support, research visits and doctoral program. IZA engages in (i) original and internationally competitive research in all fields of labor economics, (ii) development of policy concepts, and (iii) dissemination of research results and concepts to the interested public.
\end{abstract}

IZA Discussion Papers often represent preliminary work and are circulated to encourage discussion. Citation of such a paper should account for its provisional character. A revised version may be available directly from the author. 
IZA Discussion Paper No. 9355

September 2015

\section{ABSTRACT}

\section{Sex, Race, and Job Satisfaction among Highly Educated Workers*}

There has been a considerable amount of work focusing on job satisfaction and sex, generally finding that women are more satisfied than men despite having objectively worse job conditions. But there is little evidence on whether job satisfaction differs by race or ethnicity. We use data from the 2010 National Survey of College Graduates to examine the relation between job satisfaction and race and ethnicity among Asian, black, Hispanic/Latino, and white workers. Overall job satisfaction does not differ by sex among college graduates. Relative to white workers of the same sex, Asian and black workers are far less satisfied. The lower satisfaction of Asian and black workers relative to white workers is not explained by immigrant status, job match, or other individual or job characteristics.

JEL Classification: J15, J16, J28, J71

Keywords: job satisfaction, gender, race and ethnicity, immigrants, college graduates, discrimination

Corresponding author:

Joni Hersch

Vanderbilt Law School

Vanderbilt University

131 21st Avenue South

Nashville, TN 37203

USA

E-mail: Joni.hersch@vanderbilt.edu

* We thank Barry Hirsch and participants at the Southern Economic Association 2014 annual meeting in the session "Gender and the Labor Market" for their comments. 


\section{Sex, Race, and Job Satisfaction Among Highly Educated Workers}

\section{Introduction}

There is substantial economics literature concerning sex differences in job satisfaction, ${ }^{1}$ but very little work that investigates racial or ethnic differences in job satisfaction. In this paper, we examine the relation between race or ethnicity and job satisfaction among a large sample of college graduates.

Studies of the relation between sex and job satisfaction typically find that, despite having lower pay and fewer opportunities for advancement — which may be related to discriminatory treatment-women are more satisfied than men with their jobs. Possible explanations for this apparent paradox include sex differences in values, in job expectations, and in labor force participation rates. Women appear to value high pay and opportunities for advancement less than men do, and women also appear to have lower expectations about their pay and prospects for promotion and therefore may be more easily satisfied. Further, women who are not satisfied with their jobs may choose to stay out of the labor market, so that the women who are employed are on average more satisfied. The finding that women are on average more satisfied suggests that the positive effect on job satisfaction of differences in values, lower expectations, and selection into the labor market of those who are more satisfied with their jobs outweighs the negative effect on job satisfaction of discriminatory treatment.

There is little evidence on whether nonwhite workers likewise experience a job satisfaction differential relative to white workers. However, the reasons that job satisfaction may differ by sex - that is, discriminatory treatment and differences in expectations, values, or labor force participation-may also pertain to race or ethnicity.

Although some papers that examine the relation between sex and job satisfaction include an indicator for black workers and find that black workers have lower job satisfaction (e.g., Donohue and Heywood 2004), there is little investigation into the source of this racial differential. Notable exceptions are papers by Bartel (1981), who uses data from the National Longitudinal Surveys of Mature Men, and Mukerjee (2014), who uses data from the General Social Survey and the National Longitudinal Survey of Youth. Bartel (1981) finds that blacks

\footnotetext{
${ }^{1}$ See, e.g., Clark (1997); Sloane and Williams (2000); Sousa-Poza and Sousa-Poza (2000); Ward and Sloane (2000); Donohue and Heywood (2004); Bender, Donohue, and Heywood (2005); Westover (2012). As we discuss later, these studies also provide evidence on sex differences in work values and job expectations.
} 
report significantly higher job satisfaction. She surmises that blacks have lower expectations due to discrimination, and thus, job expectations are more easily fulfilled for blacks. In contrast, Mukerjee (2014) finds that blacks report significantly lower job satisfaction and that controlling for perceived discrimination eliminates the black-white gap in job satisfaction. This suggests that any lowering of expectations among black workers, as posited by Bartel (1981), is not sufficient to offset the direct effect of perceived discriminatory treatment.

Most of the datasets that have been used to examine job satisfaction have too few observations to provide adequate statistical power to examine workers of any race other than black or white. By using data from the 2010 National Survey of College Graduates (NSCG), which includes information on more than 77,000 college graduates, we have a large enough sample to examine workers of the Asian race and those of Hispanic/Latino ethnicity, as well as those of black and white races. ${ }^{2}$ The NSCG is a nationally representative survey of college graduates. In addition to highly detailed demographic and labor market information, the NSCG requests unusually extensive information on job satisfaction, with respondents reporting their satisfaction for nine separate dimensions of their job, as well as overall satisfaction that is typically used in job satisfaction studies. We augment the data available in the NSCG with information on occupational characteristics from the Current Population Survey (CPS) and on working conditions from the Department of Labor Occupational Information Network (O*NET) database.

The contributions of this paper include providing additional evidence on sex differences in job satisfaction using data on a large sample of college graduates; providing unique information on whether job satisfaction differs by race or ethnicity; and providing unique information on how satisfaction with specific aspects of the job differs by sex, race, or ethnicity. We examine whether racial or ethnicity differences in job satisfaction are related to differences in the population share who are immigrants, as well as whether job satisfaction differs within

\footnotetext{
${ }^{2}$ We recognize that because the NSCG includes only those who are college graduates, our results may not be directly comparable to studies that are not restricted to those with college degrees. However, there are no other datasets with information on job satisfaction and the labor market that have a sufficient number of observations to provide adequate statistical power to examine races other than black or white. For example, even pooling multiple years of the General Social Survey would not avoid the sample size limitation because until 2000 race was recorded only as black, white, or other, and Hispanic ethnicity was not recorded. Although the Behavioral Risk Factor Surveillance System records have detailed race information and a large number of observations, this survey includes questions about life satisfaction and not about job satisfaction.
} 
race or ethnicity by immigrant status. We also account for job match, unaccounted for in most of the previous gender and race job satisfaction literature.

\section{Theoretical and Empirical Framework}

Conceptually, overall utility can be represented by $v=v(u, \mu)$, where $u(\cdot)$ is a sub-utility function that captures utility from work and $\mu$ captures utility from other facets of life such as relationships with friends and family (Clark and Oswald 1996). Work utility takes the form (1) $u=u(y, h, x, c)$, where $y$ is income, $h$ is the number of hours worked, $x$ is a vector of individual characteristics, and $c$ is a vector of job-specific characteristics.

We use the NSCG job satisfaction measure as a proxy for utility from employment, recognizing that utility from other facets of life embodied in the term $\mu$ may spill over and influence utility as well as choices related to employment. A worker’s job satisfaction captures the worker's reaction to the "entire panoply of job characteristics” (Hamermesh 2001, p. 2). Scholars have found job satisfaction to be correlated with quit intentions or turnover (Freeman 1978; Hersch and Stone 1990; Clark 2001; Lee 2012), worker absenteeism (Clegg 1983), worker productivity (Mangione and Quinn 1975), and organizational performance (Ostroff 1992).

We estimate job satisfaction equations with the general form of (2) $s_{i}=\alpha+\beta x_{i}+\delta c_{i}+\varepsilon$,

where $s$ is a measure of job satisfaction, $x$ is a vector of individual characteristics including sex, race, and ethnicity, and $c$ is a vector of job-specific characteristics including income, hours worked, and working conditions.

We are interested in whether there are sex, race, or ethnicity differences in job satisfaction. As discussed earlier, there is substantial literature examining sex and job satisfaction but little literature examining the relation between race or ethnicity and job satisfaction. Many of the arguments offered to explain sex disparities in satisfaction are relevant to race and ethnicity as well, so we start by reviewing the hypotheses that relate sex to job satisfaction in order to motivate our empirical specification.

First, past studies have noted that women value intangible aspects of the job such as good relationships and the actual work itself more than men do, and men value the tangibles such as salary and promotions more than women do (Clark 1997). If values differ by sex and workers choose jobs based on their values, studies that do not control for less-quantifiable job aspects that 
may be correlated with sex, such as workplace relationships, suffer from omitted variable bias. In this case, the sex disparity would disappear if information on actual working conditions or individual work values are taken into account. Bender, Donohue, and Heywood (2005) and Ward and Sloane (2000) find that controlling for work values eliminates the unadjusted satisfaction differential by sex. ${ }^{3}$ Similar arguments may pertain to race or ethnicity if work values differ by race or ethnicity. Because workers may sort into occupations on the basis of work values, we control for both occupation and occupational characteristics in the job satisfaction equations.

Second, women may expect less from their job than men, and thus, job expectations may be more easily fulfilled for women. Or, relatedly, job satisfaction may be determined relative to others; that is, expectations may be based on a reference point. There is indirect evidence supporting this hypothesis. The differential in satisfaction by sex disappears for certain groups of workers who are likely to have similar expectations. Clark (1997) finds no differential in overall satisfaction for the young, the well-educated, and those in professional occupations. Donohue and Heywood (2004) find no differential in their full sample of young workers. ${ }^{4}$ Ward and Sloane (2000) find no differential in overall satisfaction for their sample of academics. Clark (1997) and Sloane and Williams (2000) find that controlling for a measure of comparison income decreases the size of the satisfaction differential between men and women. The influence of expectations on job satisfaction observed in comparing male and female workers may also pertain to race and ethnicity. Nonwhites in general may expect less from their jobs and therefore be more easily satisfied, although we anticipate that the college graduates in our sample may have expectations that are more similar than those of the general population.

Third, the satisfaction differential by sex may be attributed to different labor force participation rates, with women who are genuinely dissatisfied with their jobs choosing to not participate in the labor market. That is, the lower labor market participation rate of women may reflect the fact that job satisfaction or dissatisfaction forms a component of the opportunity cost

\footnotetext{
${ }^{3}$ Bender, Donohue, and Heywood (2005) use the 1997 National Study of the Changing Workforce and find that the sex difference in satisfaction becomes statistically insignificant after controlling for whether "employees have to choose between advancing in their jobs or devoting attention to their family or personal lives." Based on data from Scottish academics, Ward and Sloane (2000) find that controlling for work values eliminates the unadjusted satisfaction differentials by sex for salary satisfaction and job security satisfaction. Work values in their study include "teaching importance" and "relationships with colleagues importance."

${ }^{4}$ Using data from the 1979 National Longitudinal Survey of Youth, Donohue and Heywood (2004) find the satisfaction disparity by sex becomes insignificant after controlling for fringe benefits such as the availability of childcare, paid vacation days, and a profit-sharing plan.
} 
of market work relative to nonmarket work. Workers associate a higher reservation wage to lowsatisfaction jobs and a lower reservation wage to high-satisfaction jobs. The influence of job satisfaction on the reservation wage may lead to sorting of women with higher levels of job satisfaction into the labor market. This participation hypothesis emphasizes the importance of taking into account selection into the labor force in estimating the relation between sex and job satisfaction. It is notoriously hard to find credible instruments for the labor force participation decision, and with the exception of Clark (1997), who finds that selection does not explain the satisfaction disparity between men and women, studies do not correct for possible sample selection bias. Later, we discuss whether differences in labor force participation may be relevant in explaining job satisfaction differentials on the basis of race or ethnicity.

Because the share of a population who are immigrants differs by race and ethnicity, with a large share of Asians and Hispanics/Latinos who are immigrants to the United States, racial or ethnic differences in job satisfaction may actually reflect the distribution of immigrants within the different racial and ethnic groups. Therefore, we also examine whether job satisfaction differs within race or ethnicity by immigrant status. Immigrants' job satisfaction may differ from that of their same race or ethnic counterparts. They may have lower job satisfaction if they face greater discrimination or if they have higher expectations, to the extent that immigrants are positively selected on the basis of characteristics like skills and ambition. Immigrants may instead have higher job satisfaction than their same race or ethnic counterparts if they have lower expectations due to less familiarity with the language or culture of the United States. To our knowledge, the only paper that has explored differentials in job satisfaction by immigrant status is McGuinness and Byrne (2014), who find that female immigrants, but not male immigrants, have lower job satisfaction than their same-sex native-born counterparts within a sample of graduates of European universities. Their data does not allow an examination of ethnic differentials.

Finally, studies find that workers who have better education or skill matches are more satisfied with their jobs (e.g., Hersch 1991; Allen and van der Velden 2001), but job match has not been widely accounted for in the sex and race job satisfaction literature. In situations of job mismatch, there is a higher likelihood that workers' job expectations are not met. To the extent that job match quality differs by sex, race, ethnicity, or immigrant status, part of any satisfaction 
differential may be attributable to job match quality. We therefore control in the estimates for job match quality.

\section{Data Sources and Variable Definitions}

Our source for individual data is the 2010 National Survey of College Graduates (NSCG). ${ }^{5}$ To be included in the NSCG sample, individuals must have a bachelor's or higher degree and be under 76 years old and not institutionalized as of the survey reference date (October 1, 2010). The number of observations in the full sample is 77,188. Job satisfaction questions are asked only of those employed as of the survey reference date, and we additionally exclude from our analyses those missing salary or reporting zero salary on current job, as well as those with a non-U.S. work location. This leaves us with 61,870 observations for most of the analyses of this paper. ${ }^{6}$ We use the 2010 NSCG sampling weights to account for the survey's sample design in the reported descriptive statistics and regression results.

We describe the key variables used in the analyses below, starting with the job satisfaction, race, and ethnicity measures, followed by individual characteristics and job characteristics including income, hours worked, and measures of working conditions. Descriptive statistics for all variables defined below are reported in Appendix 2 for the full sample and by sex; descriptive statistics by race or ethnicity are reported in Appendix 3.

The NSCG asks respondents to rate their satisfaction on a four-point scale (very dissatisfied, somewhat dissatisfied, somewhat satisfied, or very satisfied) with nine aspects of their principal job: salary, benefits, job security, job location, opportunities for advancement, intellectual challenge, level of responsibility, degree of independence, and contribution to society. After rating their satisfaction with these specific aspects, respondents are asked to rate their overall satisfaction with their job. Our analyses start by examining this measure of overall job satisfaction. For each of the satisfaction questions, the responses are highly concentrated at the upper end (i.e., somewhat satisfied and very satisfied). We create an indicator variable for each measure of job satisfaction where the variable is equal to 1 if the respondent answers very satisfied.

\footnotetext{
${ }^{5}$ See http://www.nsf.gov/statistics/srvygrads/. The 2003 NSCG also includes information on job satisfaction and most of the information used in this paper, but information on fringe benefits that is reported in 2010 is not available in 2003, so we use only the 2010 wave in this paper.

${ }^{6}$ See Appendix 1 for more information on the construction of the sample.
} 
In addition to an indicator variable for sex, we create indicators for mutually exclusive race and ethnicity categories, as well as an indicator for immigrants. All respondents reporting Hispanic, Latino, or Spanish origin (any race) are identified by an indicator variable. We then create mutually exclusive non-Hispanic or Latino race categories for those reporting only one race of Asian, black, or white. Non-Hispanic individuals of any other race (specifically Native Hawaiian or other Pacific Islander, or American Indian or Alaska Native) and reporting more than one race are grouped in an 'other race' category. The respondent is categorized as an immigrant if the respondent was not a U.S. citizen born in the United States, Puerto Rico, or another U.S. territory, or was not born of U.S. citizen parent(s). Whether an individual is an immigrant to the United States varies considerably by race and ethnicity. ${ }^{7}$ We also create mutually exclusive race or ethnicity categories by immigrant status in order to help identify the source of job satisfaction disparities by race or ethnicity.

Individual characteristics include detailed demographic, health, and educational information. We control for age, being married or living in a marriage-like relationship (which we refer to as 'married' for brevity), total number of children under 18 in the household, and whether the person is an immigrant. To account for health status, we use the four survey questions on functional limitations that ask the respondents to rate their difficulty with seeing, hearing, walking, and lifting. For each question, the respondent could answer no difficulty, slight difficulty, moderate difficulty, severe difficulty, or unable to do the activity in question. We create an indicator variable for each functional limitation where the variable is equal to 1 if the respondent answered moderate difficulty, severe difficulty, or unable to do the activity in question.

NSCG respondents report information on their first bachelor's degree and two most recent degrees (other than first bachelor's degree) at the bachelor's level or higher. For each degree reported, respondents provide the year the degree was obtained, the type of degree (bachelor's, master's, doctorate, or professional), and the field of study (selecting from a list of more than 140 fields). From this information, we create mutually exclusive indicator variables for the highest degree obtained: JD, MD, MBA, MA not in business, $\mathrm{PhD}$, and no graduate degree.

\footnotetext{
${ }^{7}$ Specifically, within our sample, the shares that are immigrants are as follows: white, 5\%; Asian, 81\%; black, 15\%; other race, 11\%; Hispanic/Latino, 30\%.
} 
The NSCG includes extensive information on job characteristics. Our measure of salary is basic annual salary on the principal job held as of the survey reference date. ${ }^{8}$ In the regression analyses, we control for log of own salary, which is typically found to be positively related to job satisfaction (e.g., Clark 1997; Sloane and Williams 2000). Fringe benefits form an additional component of pay. Respondents are asked whether any of these benefits were available to them, even if they chose not to take them: health insurance that is at least partially paid by employer, pension or retirement plan to which employer contributed, profit-sharing plan, and paid vacation, sick, or personal days. Because fringe benefits are a form of compensation, we expect those with fringe benefits to be more satisfied with their jobs. We also control for the log of usual hours worked per week in a typical week on the principal job. Studies (e.g., Clark 1997) have found an inverse relation between job satisfaction and hours worked per week. Tenure is the number of years that the respondent had worked for the principal employer from the time the respondent started the job to the survey's reference date.

Respondents report whether they supervise the work of others as part of their principal job, and we create a supervisor indicator variable. Firm size is reported in eight categories, from 10 or fewer employees to 25,000 or more employees. We create indicator variables for each of the provided firm size categories. We create indicator variables for type of employer: government, self-employed, non-profit, for-profit, or other employer type. We also create indicator variables for employer location based on region of country, which is reported in nine Census categories. ${ }^{9}$ To account for job match quality, we create indicator variables using respondents' report of whether their job is closely related, somewhat related, or not related to the field of their highest degree.

Occupation is reported in the NSCG by selection from a list of 132 occupations. We control in the regressions for occupation by grouping these occupations into 10 categories based on the 2010 Standard Occupational Classification (SOC) intermediate aggregation level categories. ${ }^{10}$

\footnotetext{
${ }^{8}$ The specific question is: "Before deductions, what was your basic annual salary on this job [that is, the principal job] as of the week of October 1, 2010?" The question includes this instruction in parentheses: "Do not include bonuses, overtime, or additional compensation for summertime teaching or research.” Those who are not salaried are asked to estimate their earned income, excluding business expenses.

${ }^{9}$ No other locational information such as SMSA or city size is available.

${ }^{10}$ These occupations are management, business, and financial; computer, engineering, and science; education, legal, and community service; arts and media; healthcare practitioners and technical; service; sales and related; office and
} 
For comparison to other studies, we construct additional variables which we match to individuals by assigning occupational average job characteristics calculated from the CPS and O*NET database. The NSCG does not report whether an individual is a member of a union or covered by a union contract. Union status has been shown to be negatively associated with job satisfaction (e.g., Bender and Sloane 1998; Artz 2012). Artz (2012) suggests that a higher percentage of females in an organization is positively associated with job satisfaction. Along similar lines of reasoning, the percentages of different minorities at a workplace might also be important to job satisfaction. Using CPS data for the years 2008-2010, we create, by occupational category, variables for the percentage of workers in a union or covered by a union contract, female, white, Asian, black, other race, and Hispanic/Latino. To improve the precision of the match, the percentages are generated based on the 22 occupation categories in the SOC major groups categorization. ${ }^{11}$ We generate a three-year average to reduce measurement error. In order to match the variables constructed from the CPS to the NSCG, we create the same 22 occupation categories from NSCG occupation codes and link the percentages calculated from the CPS to observations in the NSCG by matching the occupation group in the CPS to the corresponding occupation group in the NSCG.

We also supplement the information available in the NSCG with data from the O*NET database, which provides ratings for many different skill requirements and work characteristics. Prior studies have used $\mathrm{O}^{*} \mathrm{NET}$ data to control for occupational characteristics in wage equations. For example, using O*NET data, Hirsch (2005) shows that much of the wage gap between full-time and part-time workers is due to occupation skill requirements and working conditions. To select specific characteristics to include in our analyses, we draw on Krueger and Schkade (2008) who show, using data that the authors themselves collected, that personal interactions on the job, an unpleasant physical work environment, and pressure at work significantly affect job satisfaction. Using O*NET data, they demonstrate that extroverted

\footnotetext{
administrative support; natural resources, construction, maintenance, production, transportation, and material moving (e.g., 'blue-collar occupations'); and other.

${ }^{11}$ The 22 occupation categories are management; business and financial operations; computer and mathematical; architecture and engineering; life, physical, and social science; community and social service; legal; education, training, and library; arts, design, entertainment, sports, and media; healthcare practitioners and technical; healthcare support; protective service; food preparation and serving related; other service; sales and related; office and administrative; farming, fishing, and forestry; construction and extraction; installation, maintenance, and repair; production; transportation and material moving; and other. Because industry is not reported in the 2010 NSCG, we are unable to match percentage unionized by industry.
} 
workers sort into occupations that involve more personal interactions with others. We therefore chose $\mathrm{O} *$ NET variables that measure personal interactions on the job, an unpleasant work environment, and pressure at work. We additionally include O*NET measures that account for physical effort required on the job, dangerousness of the job, and autonomy and structure on the job. $^{12}$

We match these $\mathrm{O}^{*}$ NET variables to individual observations in the NSCG by using a crosswalk between individual SOC codes and the NSCG occupation categories. Of the 132 occupations indicated in the NSCG, there are 7 occupations for which the O*NET variables do not have ratings and thus could not be matched to $\mathrm{O} * \mathrm{NET}$ data. In regressions controlling for O*NET characteristics, we drop the observations that could not be matched and ones for which certain O*NET variables had missing data, leaving us with 59,025 observations. ${ }^{13}$

\section{Descriptive Statistics}

Tables 1 and 2 provide descriptive statistics on overall job satisfaction by sex and race or ethnicity. Table 1 shows that there is no difference on average by sex in overall job satisfaction for the full sample. However, the overall values mask considerable differences by race or ethnicity. The difference in satisfaction between men and women who are either white or in the 'other race' category is not statistically significant. But Asian and black men are about 4 percentage points more likely than women of the same race to report that they are very satisfied, and Hispanic/Latino women are 6 percentage points more likely to report they are very satisfied than are Hispanic/Latino men. These statistics highlight the importance of considering the role of race or ethnicity in any comparison of sex differences in job satisfaction.

Furthermore, white workers have considerably higher job satisfaction than Asian and black workers of the same sex. Table 2 shows the magnitudes of the differences in percentages that are very satisfied and indicates which pairs have statistically significant differences. White

\footnotetext{
${ }^{12}$ The $\mathrm{O} *$ NET variables used here are coded on $1-5$ scales of importance, incidence, and degree. O*NET variables for personal interactions on the job (except for contact with others, deal with unpleasant or angry people, and deal with physically aggressive people) and $\mathrm{O}^{*} \mathrm{NET}$ variables for physical effort required for the job are measured on a scale of importance, from 1 (not important) to 5 (essential). O*NET variables for an unpleasant work environment, along with the variables deal with unpleasant or angry people and deal with physically aggressive people, are measured on a scale of frequency, from 1 (never) to 5 (every day). The O*NET variable contact with others, along with variables for autonomy and structure on the job, are measured on a scale of degree, from 1 (none) to 5 (a lot).

${ }^{13}$ As an alternative, we estimate regressions including indicator variables for each of the 132 NSCG occupations in the regressions. This approach directly nets out the influence on job satisfaction of working conditions associated with the individual's occupation. The estimates are very similar using either approach.
} 
and Hispanic/Latino women report similar levels of job satisfaction and are about 15 percentage points more likely to report they are very satisfied than are Asian and black women. White men report higher job satisfaction than Hispanic/Latino men, but both white and Hispanic/Latino men are more likely to report they are very satisfied than are Asian and black men. White men are about 11 percentage points more likely to report that they are very satisfied than Asian and black men, and Hispanic/Latino men are about 5 percentage points more likely to report that they are very satisfied than Asian or black men.

\section{Estimates Controlling for Individual and Job Characteristics}

In this section, we report marginal probit estimates for regressions in which the dependent variable is an indicator for those reporting very satisfied for overall job satisfaction. ${ }^{14}$ Table 3 reports estimates based on the entire sample with an indicator variable for sex, and Table 4 summarizes the coefficients on race and ethnicity for regressions that correspond to the specifications reported in Table 3 but stratified by sex. Because job characteristics may be affected by job satisfaction, we begin by reporting in column 1 of Tables 3 and 4 results from regressions that include only individual characteristics that are determined outside of the labor market. For example, if job satisfaction influences turnover, then tenure will be determined jointly with job satisfaction. A comparison of estimates with and without controls for potentially endogenously determined job characteristics provides evidence on whether the estimates on sex, race, or ethnicity are biased by potential endogeneity.

We then explore whether the racial differentials for Asian and black workers observed in the sample means are due to workers of these races sorting into occupations based on job characteristics that lead to higher or lower job satisfaction. We do this by first controlling for individual and job characteristics (reported in column 2 of Tables 3 and 4), and then controlling for individual and job characteristics as well as working conditions using $\mathrm{O}$ NET variables (reported in column 3 of Tables 3 and 4).

In the regressions with only individual characteristics reported in Table 3, column 1, first note that, similar to the overall means of job satisfaction, there is no overall disparity in job

\footnotetext{
${ }^{14}$ Estimation by ordinary least squares (OLS) produces very similar marginal effects. We also estimated ordered probit regressions where the satisfaction measure can take any value on the four-point scale and find results that are similar to those reported in this paper. Regressions which include variables calculated from the CPS and O*NET and based on clustered standard errors are similar to those reported in the tables. All results discussed in this paper but not reported in the text or appendices are available from the authors upon request.
} 
satisfaction by sex. We find that race, however, does have an important influence on job satisfaction. Specifically, when examining the entire sample with an indicator variable for sex, Asians are 6.9 percentage points less likely than whites to report that they are very satisfied, and blacks are 10.4 percentage points less likely than whites to report that they are very satisfied. For comparison, Table 1 shows an unadjusted difference in overall job satisfaction between whites and both Asians and blacks of about 13 percentage points for the pooled sample. Thus, controlling for individual characteristics reduces the unadjusted Asian to white differential by about half, but has a smaller influence on the unadjusted black to white differential.

Other individual characteristics are also associated with job satisfaction. Generally, those who are married and those with children under 18 are more likely to report that they are very satisfied, whereas those with some sort of physical difficulty (i.e., those with worse health) are less likely to report that they are very satisfied (Clark 1997; Donohue and Heywood 2004). In contrast to much of the literature, we find that those with graduate degrees are more likely to report that they are very satisfied. This is likely because our sample only contains college graduates. Immigrants report lower satisfaction. But even controlling for immigrant status, the Asian and black differentials are still statistically significant. This means that the racial differentials found should not be attributed solely to immigrant status.

Table 3, column 2, adds the NSCG and CPS job-specific controls to the specification. These results show that even though the regressions add a broad range of job characteristics that in most cases differ significantly between whites and both Asians and blacks (as indicated in Appendix Table 3), the coefficients on Asian and black change by only tenths of a percentage point either up or down, with these coefficients remaining negative and statistically significant. ${ }^{15}$

Those with higher salaries are more likely to report very satisfied while those with higher hours are less likely to report very satisfied. ${ }^{16}$ In Table 3, column 2, when the coefficients on the

\footnotetext{
${ }^{15}$ Because many of the job characteristics differ significantly by race, it may seem surprising that inclusion of job characteristics in column 2 has little effect on the magnitude of the race effects relative to the estimates in column 1 that control only for individual characteristics. However, many job characteristics are correlated with individual characteristics, such as occupation and highest degree, so the correlation with race of these job characteristics is already accounted for. In other cases, the race differences in average characteristics are small and/or the coefficients on the job characteristics are small.

${ }^{16}$ In order to examine whether differences in expectations about salary influence job satisfaction, as found in Clark (1997) and Sloane and Williams (2000), we estimated equations controlling for alternative measures of comparison salary: predicted salary; difference between predicted and actual salary; predicted salary based on the white male salary equation (assuming that the white male equation represents the nondiscriminatory salary structure); and differences between predicted salary based on the white male structure and actual salary. In most specifications,
} 
fringe benefit variables are significant, they are positive. Those who are supervisors are more likely to report that they are very satisfied. Job satisfaction is lower among employees of larger firms. Compared to those in the for-profit sector, those who work for a government employer, non-profit employer, or are self-employed are more likely to report very satisfied. Also, relative to those in management, business, and financial occupations, those in office and administrative support and blue-collar occupations are less likely to report very satisfied. These findings are standard in the empirical literature on job satisfaction.

Having a job that is closely related to one's highest degree is associated with higher job satisfaction. In contrast to much of the literature, we find that those in occupations with more unionized workers do not have statistically lower job satisfaction. The relation between job satisfaction and union status may differ from that found in other studies because our sample only contains college graduates. In the pooled regressions reported in Table 3, we find that the percent female has no significant effect on job satisfaction. However, in our regressions stratified by sex, we find that men in occupations with a greater share of women have lower job satisfaction, although the share of women in an occupation is not related to job satisfaction among women. ${ }^{17}$ This is in part consistent with Haile (2012), who suggests that the sex composition of the workplace has different effects on men and women, although Haile (2012) finds that greater gender diversity lowers job satisfaction for women and not for men.

The results reported in Table 3, column 3, show that adding the O*NET occupational characteristics slightly decreases the coefficient on Asian and increases the coefficient on black, but by only tenths of a percentage point. Very few $\mathrm{O}^{*} \mathrm{NET}$ variables individually have a significant effect on overall job satisfaction, and when they are statistically significant, the signs and significance sometimes differ between men and women. Because the insignificance of the individual working conditions may be due to collinearity, we also use factor analysis to create latent factors for personal interactions, physical effort required, unpleasant environment, dangerousness, autonomy and structure, and pressure by combining the $\mathrm{O} * \mathrm{NET}$ variables in each

comparison salary did not have a statistically significant relation with job satisfaction. Most importantly, there was very little difference in the sex and race satisfaction differentials relative to those reported in Tables 3 and 4 . Overall, these results suggest that expectations may not be an important determinant of job satisfaction among college graduates, and that the sex and racial differentials are not due to differences in expectations about income. ${ }^{17}$ In the wage context, Macpherson and Hirsch (1995) also find that the percent female in an occupation has a stronger negative effect on wages among men than among women. 
category, respectively. ${ }^{18}$ As we found when we control for individual O*NET characteristics, estimates with these latent factors show little change in the coefficients on sex, race, and ethnicity. We also find that the only factor that has a statistically significant relation with job satisfaction is the factor representing freedom to make decisions and extent of structured work, which has a positive relation in the full sample. ${ }^{19}$

Table 4 reports coefficients on race and ethnicity for estimates that stratify the sample by sex, with estimates for women summarized in Panel A and estimates for men summarized in Panel B. As in the estimates pooling men and women reported in Table 3, there is no significant difference in satisfaction between white workers and Hispanic/Latino workers or those in the 'other race’ category. Among workers of the same sex, Asian and black workers are less satisfied with their jobs relative to whites. But the gap in satisfaction between Asian and black workers relative to whites of the same sex is smaller for men than for women. As in Table 3, sequentially adding more controls usually has only a small effect on the coefficients on Asian and black. Within sex, controlling for individual characteristics reduces the unadjusted Asian to white differential (reported in Table 2) by about half, but has a smaller influence on the unadjusted black to white differential.

A possible interpretation of the smaller racial gap in satisfaction among men relative to women may relate to racial differences in labor force participation within sex. We report labor force participation rates by sex, race, and ethnicity in Table 5. The labor force participation rate of college educated men is higher for men than for women of the same race, with the exception of blacks. The labor force participation rate of black women is 9 percentage points higher than the rate of white women and, at 87 percent, is similar to that of white men. If white women who are dissatisfied with their jobs are more likely to exit the labor force than are dissatisfied black women, at least part of the satisfaction differential between black and white women may be due to selection. However, because Asian and white women have similar labor force participation rates, as do black and white men, selection is unlikely to explain the satisfaction differential between Asian and white women or between black and white men.

By including an indicator for immigrant status in Tables 3 and 4, we test whether racial or ethnic differences in job satisfaction were due to immigrant status. However, this average

\footnotetext{
18 See Hirsch and Manzella (2015) for a thorough description of how to create latent factors from O*NET variables. ${ }^{19}$ In estimates stratified by sex, this factor is statistically significant and positive for women but not for men.
} 
effect may mask heterogeneity in the effect of immigrant status by race or ethnicity. As we discussed earlier, immigrants' job satisfaction may differ from their same race or ethnic counterparts. Because the share who are immigrants differs by race and ethnicity, the substantially lower satisfaction of Asians relative to whites may be driven by the large proportion of immigrants in the sample of Asian workers, while the absence of a significant difference between Hispanic/Latino and white workers may be related to the smaller share of Hispanic/Latino workers within our sample who are immigrants. To test this hypothesis, we estimate equations that include separate indicators for race and ethnicity by immigrant status. We summarize the coefficients on race or ethnicity by immigrant status in Table 6, with estimates summarized in column 1 for the full sample, in column 2 for women, and column 3 for men. The reported estimates are based on regressions with the full set of variables corresponding to column 3 of Tables 3 and 4. That is, we control for individual characteristics, job characteristics, and $\mathrm{O}$ *NET occupational characteristics.

For women, these results show negative Asian and black satisfaction differentials regardless of immigrant status, with magnitudes that are larger (although not statistically different) for immigrants than for native-born U.S. citizens of the same race. For men, there is no difference in job satisfaction between native-born whites and Asians, showing that the Asian satisfaction differential is driven by immigrants. However, among men, there is no difference in job satisfaction between native-born whites and black immigrants, showing that the black satisfaction differential is driven by black natives. Interestingly, white male immigrants have lower job satisfaction relative to native-born white male workers.

\section{Different Aspects of Job Satisfaction}

In Tables 7 and 8, we summarize the coefficients on race and ethnicity for job satisfaction regressions based on the nine specific aspects of job satisfaction available in the NSCG. To see whether different aspects of job satisfaction differ by sex, Table 7 reports estimates pooling men and women, with an indicator for female. To examine whether there are racial or ethnic differences in specific aspects of job satisfaction within sex, Table 8 provides corresponding estimates stratified by sex. Each row reports a different regression with the dependent variable indicated in the left column, and all regressions control for the full set of individual, job, and O*NET characteristics that correspond to column 3 in Tables 3 and 4. 
Although there is no difference in overall satisfaction between men and women, Table 7 shows that women are more satisfied than men for five satisfaction measures: job location, opportunities for advancement, intellectual challenge, level of responsibility, and contribution to society. Women are no less satisfied than are men with salary, benefits, job security, and degree of independence. That is, women seem to be more satisfied than men with aspects of their jobs that seem to reflect values and preferences, suggesting that any female advantage in job satisfaction is not necessarily paradoxical.

In contrast, Table 7 shows that the negative differentials for Asians and blacks in the overall satisfaction regressions are reflected in most of the individual satisfaction measures. There is a negative Asian differential for five satisfaction measures: salary, benefits, level of responsibility, degree of independence, and contribution to society. The magnitudes are considerable, with, for instance, a gap of 5 percentage points for salary, and about 10 percentage points for benefits and degree of independence. Similarly, there is a negative black differential for six satisfaction measures: salary, job security, job location, intellectual challenge, level of responsibility, and degree of independence. There is no Hispanic/Latino or 'other race' differential in any measure of job satisfaction.

Table 8 provides corresponding estimates for different aspects of job satisfaction by sex. Reflecting their lower overall job satisfaction relative to white women, Asian and black female workers are less satisfied than white female workers on most of the nine aspects of job satisfaction. For females, there is a negative Asian differential in six satisfaction measures: salary, benefits, job security, level of responsibility, degree of independence, and contribution to society. Similarly, there is a negative black differential for seven satisfaction measures: salary, job security, job location, intellectual challenge, level of responsibility, degree of independence, and contribution to society. Other race women are less satisfied than white women with their salary, but there are otherwise no differences in satisfaction with specific job aspects between white women and those of other race or Hispanic/Latino.

Although Asian and black men report substantially lower overall job satisfaction relative to white men, they are less likely than are women to report lower satisfaction with specific aspects of their jobs. Asian men report lower satisfaction than white men in three areas: salary, benefits, and degree of independence. There are no differentials between black and white men in 
any of the specific aspects of job satisfaction, nor are there any differences between men who are other race or Hispanic/Latino and white men in any of the specific measures of job satisfaction.

It is clear from the results in Table 8 that Asian and black women are less satisfied with many specific job aspects than are white women, which helps explain their lower overall job satisfaction relative to white women. Asian men likewise are less satisfied than white men with three of the specific job aspects, which likewise helps explain their lower overall job satisfaction. But black men do not report lower satisfaction than white men with respect to any of the specific job aspects, making it puzzling why they report such substantially lower overall job satisfaction. It is possible that the sources of lower job satisfaction among black men are not measured by the nine specified job aspects and that the lower satisfaction may reflect a more generalized form of discriminatory treatment.

\section{Conclusion}

There has been little research examining the relation between race or ethnicity and job satisfaction, and there is no evidence on whether job satisfaction differs within race by immigrant status. Our work presents a contribution in this area. Using data from the National Survey of College Graduates and controlling for detailed individual and job-specific characteristics, we find little evidence that overall job satisfaction differs between men and women. Additionally, women are more satisfied than are men with many job aspects including intellectual challenge and contribution to society. These results, among college graduates who are expected to have similar expectations, seem to suggest that discrimination is not a major source of workplace dissatisfaction among women or, at the very least, that the effect of lower expectations in combination with lower labor force participation among women outweighs the effect of perceived or actual employment discrimination.

In contrast, we find that, relative to white workers, Asian and black workers have substantially lower overall job satisfaction, and Asian men and women and black women are less satisfied with many specific aspects of their jobs. Because we include extensive controls for individual and job characteristics, omitted variables representing individual heterogeneity or group-wide differences in values are not likely to account for the large disparities in job satisfaction. In fact, although inclusion of individual premarket characteristics reduced the unadjusted Asian and black satisfaction differential relative to whites, the satisfaction gap was only slightly reduced by inclusion of additional detailed job characteristics information. Thus, for 
unobserved individual heterogeneity to have an important influence in potentially reducing the racial satisfaction differential, the omitted characteristics would need to have a stronger influence on satisfaction than observed characteristics, have a low correlation with observed characteristics included in the regressions, and would have to be distributed in such a way that white workers are more satisfied than other workers.

Although we establish that Asian and black workers have lower job satisfaction than their white counterparts, one limitation of our study is that we are not able to distinguish between differences in expectations and discrimination as the source of lower job satisfaction. A second limitation of our study is that only college graduates are represented, which means that the results may not generalize to the entire labor market. In particular, even though Hispanics/Latinos in the United States generally fare far worse than whites in terms of education and earnings, the absence of a job satisfaction differential between whites and Hispanics/Latinos in this study suggests that college educated Hispanics/Latinos are similar to college educated whites in their expectations or experience with discrimination.

Because turnover is related to job satisfaction, the lower job satisfaction of Asian and black workers even in regressions that control for income and fringe benefits suggests that nondiscrimination in pay may not be sufficient for firms to maintain a diverse workforce. Employers should consider whether other environmental characteristics are disproportionately lowering the job satisfaction of Asian and black workers. Future research would benefit from data that tracks actual turnover as well as provides more information on employers and employees. 


\section{References}

Allen, Jim, and Rolf van der Velden. 2001. Educational Mismatches versus Skill Mismatches: Effects on Wages, Job Satisfaction, and On-the-Job Search. Oxford Economic Papers 53(3): 434-52.

Artz, Benjamin. 2012. Does the Impact of Union Experience on Job Satisfaction Differ by Gender? Industrial and Labor Relations Review 65(2): 225-43.

Bartel, Ann P. 1981. Race Differences in Job Satisfaction: A Reappraisal. Journal of Human Resources 16(2): 294-303.

Bender, Keith A., and Peter J. Sloane. 1998. Job Satisfaction, Trade Unions, and Exit-Voice Revisited. Industrial and Labor Relations Review 51(2): 222-40.

Bender, Keith A., Susan M. Donohue, and John S. Heywood. 2005. Job Satisfaction and Gender Segregation. Oxford Economic Papers 57(3): 479-96.

Clark, Andrew E. 1997. Job Satisfaction and Gender: Why are Women so Happy at Work? Labour Economics 4(4): 341-72.

Clark, Andrew E. 2001. What Really Matters in a Job? Hedonic Measurement Using Quit Data. Labour Economics 8(2): 223-42.

Clark, Andrew E., and Andrew J. Oswald. 1996. Satisfaction and Comparison Income. Journal of Public Economics 61(3): 359-81.

Clegg, Chris W. 1983. Psychology of Employee Lateness, Absence, and Turnover: A Methodological Critique and an Empirical Study. Journal of Applied Psychology 68(1): 88-101.

Donohue, Susan M., and John S. Heywood. 2004. Job Satisfaction and Gender: An Expanded Specification from the NLSY. International Journal of Manpower 25(2): 211-38.

Freeman, R. B. 1978. Job Satisfaction as an Economic Variable. American Economic Review 68(2): 135-41.

Haile, Getinet Astatike. 2012. Unhappy Working with Men? Workplace Gender Diversity and Job-Related Well-Being in Britain. Labour Economics 19(3): 329-50.

Hamermesh, Daniel S. 2001. The Changing Distribution of Job Satisfaction. Journal of Human Resources 36(1): 1-30.

Hersch, Joni. 1991. Education Match and Job Match. Review of Economics and Statistics 73(1): 140-44. 
Hersch, Joni, and Joe A. Stone. 1990. Is Union Job Dissatisfaction Real? Journal of Human Resources 25(4): 736-51.

Hirsch, Barry T. 2005. Why Do Part-Time Workers Earn Less? The Role of Worker and Job Skills. Industrial and Labor Relations Review 58(4): 525-51.

Hirsch, Barry T., and Julia Manzella. 2015. Who Cares - and Does It Matter? Measuring Wage Penalties for Caring Work. In Research in Labor Economics 41, edited by Solomon W. Polachek, Konstantinos Tatsiramos, and Klaus F. Zimmermann. Bingley, United Kingdom: Emerald Publishing Group, pp. 213-75.

Krueger, Alan B., and David Schkade. 2008. Sorting in the Labor Market: Do Gregarious Workers Flock to Interactive Jobs? Journal of Human Resources 43(4): 859-83.

Lee, Tae Heon. 2012. Gender Differences in Voluntary Turnover: Still a Paradox? International Business Research 5(10): 19-28.

Macpherson, David A., and Barry T. Hirsch. 1995. Wages and Gender Composition: Why Do Women’s Jobs Pay Less? Journal of Labor Economics 13(3): 426-71.

Mangione, Thomas W., and Robert P. Quinn. 1975. Job Satisfaction, Counterproductive Behavior, and Drug Use at Work. Journal of Applied Psychology 60(1): 114-16.

McGuinness, Seamus, and Delma Byrne. 2014. Examining the Relationships Between Labour Market Mismatches, Earnings and Job Satisfaction Among Immigrant Graduates in Europe. IZA Discussion Paper No. 8440.

Mukerjee, Swati. 2014. Job Satisfaction in the United States: Are Blacks Still More Satisfied? Review of Black Political Economy 41(1): 61-81.

Ostroff, Cheri. 1992. The Relationship Between Satisfaction, Attitudes and Performance: An Organizational Level Analysis. Journal of Applied Psychology 77(6): 963-74.

Sloane, P. J., and H. Williams. 2000. Job Satisfaction, Comparison Earnings, and Gender. Labour 14(3): 473-502.

Sousa-Poza, Alfonso, and Andrés A. Sousa-Poza. 2000. Taking Another Look at the Gender/JobSatisfaction Paradox. Kyklos 53(2): 135-52.

Ward, Melanie E., and Peter J. Sloane. 2000. Non-Pecuniary Advantages Versus Pecuniary Disadvantages; Job Satisfaction Among Male and Female Academics in Scottish Universities. Scottish Journal of Political Economy 47(3): 273-303.

Westover, Jonathan H. 2012. The Job Satisfaction-Gender Paradox Revisited: A Cross-National Look at Gender Differences in Job Satisfaction, 1989-2005. Journal of Global Responsibility 3(2): 263-77. 
Table 1. Percentage Reporting Very Satisfied for Overall Job Satisfaction by Sex, Race, and Ethnicity

\begin{tabular}{|l|l|l|c|l|}
\hline & Female & Male & All & N \\
\hline White & 48.02 & 47.67 & 47.84 & 38,149 \\
\hline Asian & 32.57 & $36.17^{* *}$ & 34.64 & 10,119 \\
\hline Black & 33.20 & $37.17^{* *}$ & 34.83 & 5,629 \\
\hline Other Race & 38.26 & 41.56 & 39.80 & 1,756 \\
\hline Hispanic/Latino & $47.16^{* *}$ & 40.91 & 44.23 & 6,217 \\
\hline All & 45.48 & 45.51 & 45.50 & 61,870 \\
\hline $\mathrm{N}$ & 26,125 & 35,745 & 61,870 & \\
\hline
\end{tabular}

Authors' calculations are from the 2010 National Survey of College Graduates. All values are calculated using the NSCG sample weight. Overall job satisfaction equals 1 if very satisfied and 0 if somewhat satisfied, somewhat dissatisfied, or very dissatisfied. Differences in percentages between female and male within race or ethnicity are tested using the Bonferroni comparison test, with asterisks associated with the group with higher value. * significant at $5 \%$ level; ** significant at $1 \%$ level. 
Table 2. Differences in Overall Job Satisfaction by Race and Ethnicity Within Sex

Panel A: Female $(\mathrm{N}=26,125)$

\begin{tabular}{|l|c|c|c|c|}
\hline & White & Asian & Black & Other Race \\
\hline Asian & $-15.46^{* *}$ & --- & --- & --- \\
\hline Black & $-14.83^{* *}$ & 0.63 & --- & --- \\
\hline Other Race & $-9.76^{* *}$ & $5.69^{*}$ & 5.06 & --- \\
\hline Hispanic/Latino & -0.86 & $14.59^{* *}$ & $13.96^{* *}$ & $8.90^{* *}$ \\
\hline
\end{tabular}

Panel B: Male $(\mathrm{N}=35,745)$

\begin{tabular}{|l|c|c|c|c|}
\hline & White & Asian & Black & Other Race \\
\hline Asian & $-11.50^{* *}$ & --- & --- & --- \\
\hline Black & $-10.50^{* *}$ & 1.00 & --- & --- \\
\hline Other Race & $-6.11^{* *}$ & $5.39^{*}$ & 4.39 & --- \\
\hline Hispanic/Latino & $-6.76^{* *}$ & $4.74^{* *}$ & $3.74^{*}$ & -0.65 \\
\hline
\end{tabular}

Authors' calculations are from the 2010 National Survey of College Graduates. All values are calculated using the NSCG sample weight. Overall job satisfaction equals 1 if very satisfied and 0 if somewhat satisfied, somewhat dissatisfied, or very dissatisfied. The magnitude of the difference between the row variable mean minus the column variable mean is reported. Differences in percentages between race or ethnicity among those of the same sex are tested using the Bonferroni comparison test. * significant at $5 \%$ level; ** significant at $1 \%$ level. 
Table 3. Overall Job Satisfaction Regressions - Pooled by Sex

\begin{tabular}{|l|c|c|c|}
\hline & $(1)$ & $(2)$ & $(3)$ \\
\hline Female & 0.013 & 0.021 & 0.020 \\
\hline & $(0.011)$ & $(0.012)$ & $(0.012)$ \\
\hline Asian & $-0.069^{* *}$ & $-0.065^{* *}$ & $-0.061^{* *}$ \\
\hline & $(0.020)$ & $(0.020)$ & $(0.021)$ \\
\hline Black & $-0.104^{* *}$ & $-0.105^{* *}$ & $-0.108^{* *}$ \\
\hline Other Race & $(0.022)$ & $(0.022)$ & $(0.022)$ \\
\hline & -0.050 & -0.061 & -0.062 \\
\hline Hispanic/Latino & $0.039)$ & $0.041)$ & $0.042)$ \\
\hline & 0.006 & 0.008 & 0.011 \\
\hline Immigrant & $(0.023)$ & $(0.023)$ & $(0.023)$ \\
\hline & $-0.083^{* *}$ & $-0.061^{* *}$ & $-0.060^{* *}$ \\
\hline Age & $0.017)$ & $0.017)$ & $0.018)$ \\
\hline Age squared/100 & $-0.007^{*}$ & $-0.015^{* *}$ & $-0.015^{* *}$ \\
\hline Married & $0.012^{* *}$ & $0.020^{* *}$ & $0.020^{* *}$ \\
\hline Children under 18 in household & $0.060^{* *}$ & $0.045^{* *}$ & $0.044^{* *}$ \\
\hline Difficulty with seeing & $0.020^{* *}$ & $0.015^{* *}$ & $0.014^{*}$ \\
\hline Difficulty with hearing & $-0.075^{*}$ & $-0.077^{*}$ & $-0.079^{*}$ \\
\hline Difficulty with walking & $-0.065^{*}$ & -0.061 & -0.060 \\
\hline Difficulty with lifting & 0.004 & 0.012 & 0.015 \\
\hline JD & -0.023 & -0.007 & -0.006 \\
\hline MD & $0.068^{*}$ & -0.009 & 0.036 \\
\hline MBA & $0.215^{* *}$ & 0.044 & -0.011 \\
\hline MA not in business & -0.007 & -0.044 & -0.040 \\
\hline PhD & $0.081^{* *}$ & 0.017 & 0.012 \\
\hline Log(salary) & $0.101^{* *}$ & -0.003 & -0.021 \\
\hline Health insurance & & $0.067^{* *}$ & $0.070^{* *}$ \\
\hline Pension plan & & 0.015 & 0.016 \\
\hline Profit-sharing plan & & $0.037^{*}$ & $0.039^{*}$ \\
\hline Paid vacation, sick, or personal days & & $0.087^{* *}$ & $0.087^{* *}$ \\
\hline Log(hours) & & 0.009 & 0.005 \\
\hline Tenure & & $-0.050^{* *}$ & $-0.052^{* *}$ \\
\hline Tenure squared/100 & & -0.003 & -0.003 \\
\hline Supervisor & $0.014^{*}$ & $0.013^{*}$ \\
\hline Government employer & & $0.049^{* *}$ & $0.041^{* *}$ \\
\hline Self-employed & $0.127^{* *}$ & $0.123^{* *}$ \\
\hline Non-profit employer & $0.049^{* *}$ & $0.048^{* *}$ \\
\hline Other type of employer & & $0.132^{* *}$ & $0.122^{* *}$ \\
\hline Computer, engineering, \& science & & 0.040 & 0.044 \\
\hline Education, legal, \& community & -0.039 & $-0.096^{*}$ \\
\hline service & -0.022 & -0.044 \\
\hline Arts \& media & & -0.059 & -0.040 \\
\hline
\end{tabular}




\begin{tabular}{|c|c|c|}
\hline Healthcare practitioners \& technical & 0.022 & -0.004 \\
\hline Service & -0.132 & -0.179 \\
\hline Sales \& related & -0.063 & -0.071 \\
\hline Office $\&$ administrative support & $-0.119 * *$ & $-0.113^{*}$ \\
\hline Blue-collar & $-0.160 *$ & -0.134 \\
\hline Other occupation & -0.034 & -0.136 \\
\hline Degree closely related & $0.125^{* *}$ & $0.122^{* *}$ \\
\hline Degree somewhat related & 0.027 & 0.027 \\
\hline Union percent & 0.230 & 0.343 \\
\hline Female percent & -0.078 & -0.208 \\
\hline Asian percent & 0.261 & 0.892 \\
\hline Black percent & -0.303 & -0.221 \\
\hline Other race percent & 3.144 & 6.919 \\
\hline Hispanic percent & 0.721 & 0.809 \\
\hline $\begin{array}{l}\text { Communicating with supervisors, } \\
\text { peers, or subordinates }\end{array}$ & & -0.021 \\
\hline $\begin{array}{l}\text { Communicating with persons outside } \\
\text { the organization }\end{array}$ & & -0.022 \\
\hline $\begin{array}{l}\text { Establish and maintaining } \\
\text { interpersonal relationships }\end{array}$ & & 0.062 \\
\hline $\begin{array}{l}\text { Perform or working directly with the } \\
\text { public }\end{array}$ & & 0.001 \\
\hline $\begin{array}{l}\text { Provide consultation and advice to } \\
\text { others }\end{array}$ & & -0.014 \\
\hline Contact with others & & $-0.097 *$ \\
\hline Work with group or team & & $0.086^{* *}$ \\
\hline Deal with external customers & & 0.033 \\
\hline Deal with unpleasant or angry people & & 0.017 \\
\hline $\begin{array}{l}\text { Deal with physically aggressive } \\
\text { people }\end{array}$ & & -0.022 \\
\hline Static strength & & 0.034 \\
\hline Explosive strength & & -0.004 \\
\hline Dynamic strength & & -0.087 \\
\hline Trunk strength & & 0.040 \\
\hline Stamina & & -0.044 \\
\hline $\begin{array}{l}\text { Sounds, noise level are distracting or } \\
\text { uncomfortable }\end{array}$ & & -0.022 \\
\hline Very hot or cold temperatures & & -0.044 \\
\hline Exposed to contaminants & & 0.040 \\
\hline Exposed to hazardous conditions & & 0.011 \\
\hline Exposed to hazardous equipment & & -0.044 \\
\hline $\begin{array}{l}\text { Exposed to minor burns, cuts, bites, or } \\
\text { stings }\end{array}$ & & 0.039 \\
\hline Freedom to make decisions & & 0.061 \\
\hline Degree of automation & & 0.011 \\
\hline
\end{tabular}




\begin{tabular}{|l|c|c|c|}
\hline Importance of repeating the same tasks & & & -0.013 \\
\hline Extent of structured work & & & -0.015 \\
\hline Level of competition & & & -0.005 \\
\hline Time pressure & & & -0.036 \\
\hline $\mathrm{N}$ & 61,870 & 61,870 & 59,025 \\
\hline Pseudo R-Squared & 0.0263 & 0.0704 & 0.0732 \\
\hline Log Likelihood & -41511 & -39634 & -37708 \\
\hline
\end{tabular}

Authors' calculations are from the 2010 National Survey of College Graduates in conjunction with CPS and O*NET data. All values are calculated using the NSCG sample weight. Overall job satisfaction equals 1 if very satisfied and 0 if somewhat satisfied, somewhat dissatisfied, or very dissatisfied. The values listed are marginal effects from probit estimation using robust standard errors. To save space, standard errors are reported in parentheses only for the coefficients on sex, race, ethnicity, and immigrant status. Firm size and employer location indicators are also included in the regressions reported in columns 2 and 3, but the coefficients are not reported in the table. * significant at 5\% level; ** significant at $1 \%$ level. 
Table 4. Overall Job Satisfaction Regressions by Sex

Panel A: Female

\begin{tabular}{|l|c|c|c|}
\hline & $(1)$ & $(2)$ & $(3)$ \\
\hline Asian & $-0.084^{* *}$ & $-0.091^{* *}$ & $-0.086^{* *}$ \\
\hline & $(0.030)$ & $(0.030)$ & $(0.031)$ \\
\hline Black & $-0.122^{* *}$ & $-0.126^{* *}$ & $-0.134^{* *}$ \\
\hline & $(0.028)$ & $(0.029)$ & $(0.029)$ \\
\hline Other Race & -0.061 & -0.066 & -0.061 \\
\hline & $(0.051)$ & $(0.052)$ & $(0.054)$ \\
\hline Hispanic/Latino & 0.034 & 0.030 & 0.033 \\
\hline & $0.031)$ & $(0.031)$ & $(0.031)$ \\
\hline Demographics & yes & yes & yes \\
\hline Job Characteristics & & yes & yes \\
\hline O*NET Variables & & & yes \\
\hline $\mathrm{N}$ & 26,125 & 26,125 & 25,294 \\
\hline Pseudo R-Squared & 0.0327 & 0.0716 & 0.0776 \\
\hline Log Likelihood & -17414 & -16712 & -16079 \\
\hline
\end{tabular}

Panel B: Male

\begin{tabular}{|l|c|c|c|}
\hline & $(1)$ & $(2)$ & $(3)$ \\
\hline Asian & $-0.059^{*}$ & $-0.052^{*}$ & -0.045 \\
\hline Black & $(0.026)$ & $(0.026)$ & $(0.028)$ \\
\hline & $-0.078^{*}$ & $-0.077^{*}$ & $-0.077^{*}$ \\
\hline Other Race & $(0.034)$ & $(0.033)$ & $(0.034)$ \\
\hline & -0.033 & -0.054 & -0.058 \\
\hline Hispanic/Latino & $(0.058)$ & $(0.060)$ & $(0.064)$ \\
\hline & -0.025 & -0.028 & -0.027 \\
\hline Demographics & $(0.032)$ & $(0.032)$ & $(0.033)$ \\
\hline Job Characteristics & yes & yes & yes \\
\hline O*NET Variables & & yes & yes \\
\hline N & & & yes \\
\hline Pseudo R-Squared & 35,745 & 35,745 & 33,731 \\
\hline Log Likelihood & 0.0236 & 0.0837 & 0.0868 \\
\hline
\end{tabular}

Authors' calculations are from the 2010 National Survey of College Graduates in conjunction with CPS and O*NET data. All values are calculated using the NSCG sample weight. Overall job satisfaction equals 1 if very satisfied and 0 if somewhat satisfied, somewhat dissatisfied, or very dissatisfied. The values listed are marginal effects from probit estimation with robust standard errors in parentheses. The regressions in column 1 also include age, marital status, children, immigrant status, health limitations, and highest degree. Column 2 adds log of real annual salary, fringe benefits, log of usual hours worked, tenure, supervisor status, firm size, type of employer, employer location, occupation categories, job's relation to highest degree, percent union, percent female, and percent of race/ethnicity. Column 3 adds O*NET occupational characteristics. * significant at $5 \%$ level; ** significant at $1 \%$ level. 
Table 5. Labor Force Participation Rates by Sex, Race, and Ethnicity

Panel A: By Sex

\begin{tabular}{|l|l|l|}
\hline & Female & Male \\
\hline White & 77.89 & $86.90^{* *}$ \\
\hline Asian & 76.05 & $90.43^{* *}$ \\
\hline Black & 87.01 & 86.80 \\
\hline Other Race & 81.13 & $91.65^{* *}$ \\
\hline Hispanic/Latino & 83.46 & $89.95^{* *}$ \\
\hline All & 78.94 & $87.49^{* *}$ \\
\hline $\mathrm{N}$ & 33,849 & 43,339 \\
\hline
\end{tabular}

Panel B: By Race (Significance Relative to White)

\begin{tabular}{|l|c|c|c|c|c|}
\hline & White & Asian & Black & Other Race & Hispanic/Latino \\
\hline Female & 77.89 & $76.05^{*}$ & $87.01^{* *}$ & 81.13 & $83.46^{* *}$ \\
\hline Male & 86.90 & $90.43^{* *}$ & 86.80 & $91.65^{* *}$ & $89.95^{* *}$ \\
\hline All & 82.27 & $83.57^{* *}$ & $86.92^{* *}$ & $85.63^{* *}$ & $86.35^{* *}$ \\
\hline $\mathrm{N}$ & 48,012 & 12,378 & 7,080 & 2,185 & 7,533 \\
\hline
\end{tabular}

Authors' calculations are from the 2010 National Survey of College Graduates. All values are calculated using the NSCG sample weight. Differences in percentages between female and male and between white and another race or ethnicity are tested using the Bonferroni comparison test. * significant at 5\% level; ** significant at $1 \%$ level. 
Table 6. Overall Job Satisfaction Regressions Accounting for Immigrant Status Within Race

\begin{tabular}{|l|c|c|c|}
\hline & All & Female & Male \\
\hline Female & 0.021 & & \\
\hline & $(0.012)$ & & $-0.061^{*}$ \\
\hline White - Immigrant & $-0.058^{*}$ & -0.059 & $(0.029)$ \\
\hline & $(0.023)$ & $(0.035)$ & -0.019 \\
\hline Asian - Native U.S. & -0.059 & $-0.109^{*}$ & $(0.049)$ \\
\hline & $(0.034)$ & $(0.044)$ & $-0.099^{* *}$ \\
\hline Asian - Immigrant & $-0.119^{* *}$ & $-0.145^{* *}$ & $(0.023)$ \\
\hline & $(0.019)$ & $(0.031)$ & $-0.080^{*}$ \\
\hline Black - Native U.S. & $-0.111^{* *}$ & $-0.135^{* *}$ & $(0.039)$ \\
\hline Black - Immigrant & $(0.024)$ & $(0.030)$ & -0.113 \\
\hline & $-0.145^{* *}$ & $-0.180^{*}$ & $(0.066)$ \\
\hline Other Race - Native U.S. & $(0.050)$ & $(0.073)$ & -0.059 \\
\hline & -0.058 & -0.055 & $(0.069)$ \\
\hline Other Race - Immigrant & $(0.045)$ & $(0.057)$ & -0.106 \\
\hline & -0.149 & -0.163 & $0.112)$ \\
\hline Hispanic/Latino - Native U.S. & $(0.107)$ & $(0.144)$ & -0.045 \\
\hline & 0.014 & 0.047 & $(0.039)$ \\
\hline Hispanic/Latino - Immigrant & $(0.027)$ & $(0.036)$ & -0.043 \\
\hline & -0.056 & -0.077 & $0.057)$ \\
\hline $\mathrm{N}$ & $(0.040)$ & $(0.055)$ & 33,731 \\
\hline Pseudo R-Squared & 59,025 & 25,294 & 0.0870 \\
\hline Log Likelihood & 0.0733 & 0.0777 & -21235 \\
\hline
\end{tabular}

Authors' calculations are from the 2010 National Survey of College Graduates in conjunction with CPS and O*NET data. All values are calculated using the NSCG sample weight. Overall job satisfaction equals 1 if very satisfied and 0 if somewhat satisfied, somewhat dissatisfied, or very dissatisfied. The values listed are marginal effects from probit estimation with robust standard errors in parentheses. All regressions also include age, marital status, children, immigrant status, health limitations, highest degree, log of real annual salary, fringe benefits, log of usual hours worked, tenure, supervisor status, firm size, type of employer, employer location, occupation categories, job's relation to highest degree, percent union, percent female, percent of race/ethnicity, and O*NET occupational characteristics. * significant at 5\% level; ** significant at $1 \%$ level. 
Table 7. Different Aspects of Job Satisfaction

\begin{tabular}{|l|l|l|l|l|c|}
\hline $\begin{array}{l}\text { Dependent Variable: } \\
\text { Satisfaction with... }\end{array}$ & Female & Asian & Black & $\begin{array}{c}\text { Other } \\
\text { Race }\end{array}$ & $\begin{array}{c}\text { Hispanic/ } \\
\text { Latino }\end{array}$ \\
\hline Salary & 0.009 & $-0.049^{* *}$ & $-0.054^{* *}$ & -0.056 & -0.013 \\
\hline & $(0.011)$ & $(0.017)$ & $(0.019)$ & $(0.032)$ & $(0.019)$ \\
\hline Benefits & 0.014 & $-0.092^{* *}$ & -0.032 & -0.057 & 0.002 \\
\hline & $(0.012)$ & $(0.019)$ & $(0.022)$ & $(0.036)$ & $(0.022)$ \\
\hline Job Security & -0.011 & -0.031 & $-0.059^{* *}$ & -0.001 & -0.010 \\
\hline & $(0.012)$ & $(0.020)$ & $(0.022)$ & $(0.039)$ & $(0.023)$ \\
\hline Job Location & $0.037^{* *}$ & -0.027 & $-0.064^{* *}$ & -0.045 & 0.028 \\
\hline & $(0.012)$ & $(0.020)$ & $(0.023)$ & $(0.038)$ & $(0.021)$ \\
\hline Opportunities for Advancement & $0.026^{*}$ & 0.009 & -0.006 & -0.028 & 0.008 \\
\hline & $(0.010)$ & $(0.018)$ & $(0.019)$ & $(0.032)$ & $(0.019)$ \\
\hline Intellectual Challenge & $0.056^{* *}$ & -0.027 & $-0.070^{* *}$ & -0.032 & 0.006 \\
\hline Level of Responsibility & $(0.012)$ & $(0.021)$ & $(0.023)$ & $(0.037)$ & $(0.023)$ \\
\hline & $0.061^{* *}$ & $-0.060^{* *}$ & $-0.063^{* *}$ & -0.050 & 0.013 \\
\hline Degree of Independence & $(0.012)$ & $(0.021)$ & $(0.024)$ & $(0.036)$ & $(0.024)$ \\
\hline & 0.015 & $-0.097^{* *}$ & $-0.060^{* *}$ & -0.043 & -0.031 \\
\hline Contribution to Society & $(0.012)$ & $(0.021)$ & $(0.023)$ & $(0.039)$ & $(0.023)$ \\
\hline & $0.036^{* *}$ & $-0.075^{* *}$ & -0.024 & -0.007 & -0.005 \\
\hline
\end{tabular}

Each row represents a different regression. $\mathrm{N}=59,025$ for all regressions. Authors' calculations are from the 2010 National Survey of College Graduates in conjunction with CPS and O*NET data. All values are calculated using the NSCG sample weight. Each job satisfaction measure equals 1 if very satisfied and 0 if somewhat satisfied, somewhat dissatisfied, or very dissatisfied. The values listed are marginal effects from probit estimation with robust standard errors in parentheses. All regressions also include age, marital status, children, immigrant status, health limitations, highest degree, log of real annual salary, fringe benefits, log of usual hours worked, tenure, supervisor status, firm size, type of employer, employer location, occupation categories, job's relation to highest degree, percent union, percent female, percent of race/ethnicity, and O*NET occupational characteristics. * significant at 5\% level; ** significant at $1 \%$ level. 
Table 8. Different Aspects of Job Satisfaction by Sex

Panel A: Females ( $\mathrm{N}=25,294)$

\begin{tabular}{|l|l|l|l|c|}
\hline $\begin{array}{l}\text { Dependent Variable: } \\
\text { Satisfaction with... }\end{array}$ & Asian & Black & $\begin{array}{c}\text { Other } \\
\text { Race }\end{array}$ & $\begin{array}{c}\text { Hispanic/ } \\
\text { Latino }\end{array}$ \\
\hline Salary & $-0.051^{*}$ & $-0.054^{*}$ & $-0.098^{* *}$ & -0.010 \\
\hline & $(0.026)$ & $(0.023)$ & $(0.028)$ & $(0.024)$ \\
\hline Benefits & $-0.119^{* *}$ & -0.037 & -0.080 & -0.018 \\
\hline & $(0.028)$ & $(0.028)$ & $(0.047)$ & $(0.030)$ \\
\hline Job Security & $-0.073^{*}$ & $-0.084^{* *}$ & -0.009 & -0.013 \\
\hline & $(0.030)$ & $(0.030)$ & $(0.053)$ & $(0.031)$ \\
\hline Job Location & -0.001 & $-0.062^{*}$ & -0.076 & 0.033 \\
\hline & $(0.031)$ & $(0.030)$ & $(0.053)$ & $(0.029)$ \\
\hline Opportunities for Advancement & -0.014 & -0.017 & -0.065 & 0.024 \\
\hline & $(0.026)$ & $(0.024)$ & $(0.036)$ & $(0.027)$ \\
\hline Intellectual Challenge & -0.045 & $-0.105^{* *}$ & -0.092 & 0.056 \\
\hline & $(0.033)$ & $(0.030)$ & $(0.047)$ & $(0.032)$ \\
\hline Level of Responsibility & $-0.088^{* *}$ & $-0.065^{*}$ & -0.093 & 0.025 \\
\hline Degree of Independence & $(0.033)$ & $(0.031)$ & $(0.050)$ & $(0.032)$ \\
\hline & $-0.089^{* *}$ & $-0.072^{*}$ & -0.031 & -0.024 \\
\hline Contribution to Society & $(0.032)$ & $(0.031)$ & $(0.051)$ & $(0.031)$ \\
\hline & $-0.132^{* *}$ & $-0.064^{*}$ & -0.015 & -0.013 \\
\hline
\end{tabular}

Panel B: Males ( $\mathrm{N}=33,731)$

\begin{tabular}{|l|c|c|c|c|}
\hline $\begin{array}{l}\text { Dependent Variable: } \\
\text { Satisfaction with... }\end{array}$ & Asian & Black & $\begin{array}{c}\text { Other } \\
\text { Race }\end{array}$ & $\begin{array}{c}\text { Hispanic/ } \\
\text { Latino }\end{array}$ \\
\hline Salary & $-0.048^{*}$ & -0.049 & 0.005 & -0.021 \\
\hline & $(0.024)$ & $(0.031)$ & $(0.054)$ & $(0.028)$ \\
\hline Benefits & $-0.072^{* *}$ & -0.022 & -0.028 & 0.019 \\
\hline & $(0.025)$ & $(0.035)$ & $(0.054)$ & $(0.033)$ \\
\hline Job Security & 0.008 & -0.013 & 0.003 & -0.011 \\
\hline & $(0.028)$ & $(0.033)$ & $(0.056)$ & $(0.033)$ \\
\hline Job Location & -0.051 & -0.050 & 0.004 & 0.015 \\
\hline Opportunities for Advancement & $(0.027)$ & $(0.034)$ & $(0.056)$ & $(0.032)$ \\
\hline & 0.035 & 0.016 & 0.028 & -0.011 \\
\hline Intellectual Challenge & $(0.024)$ & $(0.029)$ & $(0.051)$ & $(0.027)$ \\
\hline & -0.013 & -0.027 & 0.042 & -0.059 \\
\hline Level of Responsibility & $(0.027)$ & $(0.033)$ & $(0.052)$ & $(0.032)$ \\
\hline & -0.042 & -0.052 & 0.007 & -0.010 \\
\hline Degree of Independence & $(0.027)$ & $(0.035)$ & $(0.050)$ & $(0.034)$ \\
\hline & $-0.105^{* *}$ & -0.042 & -0.051 & -0.041 \\
\hline Contribution to Society & $(0.027)$ & $(0.033)$ & $(0.058)$ & $(0.032)$ \\
\hline & -0.020 & 0.040 & 0.008 & -0.003 \\
\hline
\end{tabular}


Each row represents a different regression. Authors' calculations are from the 2010 National Survey of College Graduates in conjunction with CPS and O*NET data. All values are calculated using the NSCG sample weight. Each job satisfaction measure equals 1 if very satisfied and 0 if somewhat satisfied, somewhat dissatisfied, or very dissatisfied. The values listed are marginal effects from probit estimation with robust standard errors in parentheses. All regressions also include age, marital status, children, immigrant status, health limitations, highest degree, log of real annual salary, fringe benefits, log of usual hours worked, tenure, supervisor status, firm size, type of employer, employer location, occupation categories, job's relation to highest degree, percent union, percent female, percent of race/ethnicity, and O*NET occupational characteristics. * significant at $5 \%$ level; ** significant at $1 \%$ level. 


\section{Appendix 1. Construction of Sample}

\begin{tabular}{|l|r|r|r|}
\hline & \multicolumn{1}{|c|}{ All } & \multicolumn{1}{c|}{ Female } & \multicolumn{1}{c|}{ Male } \\
\hline Initial sample & 77,188 & 33,849 & 43,339 \\
\hline Not employed in survey week & $-14,906$ & $-7,574$ & $-7,332$ \\
\hline Missing salary or reporting zero salary & -342 & -134 & -208 \\
\hline Employer location not in United States & -70 & -16 & -54 \\
\hline $\begin{array}{l}\text { Final sample size for regressions without O*NET } \\
\text { variables }\end{array}$ & 61,870 & 26,125 & 35,745 \\
\hline & & & \\
\hline Missing O*NET variables & $-2,845$ & -831 & $-2,014$ \\
\hline Final sample size for regressions with O*NET variables & 59,025 & 25,294 & 33,731 \\
\hline
\end{tabular}

Authors' calculations are from the 2010 National Survey of College Graduates in conjunction with CPS and O*NET data. 


\section{Appendix 2. Demographics and Job Characteristics Descriptive Statistics by Sex}

\begin{tabular}{|c|c|c|c|}
\hline & All & Female & Male \\
\hline \multicolumn{4}{|l|}{ Demographics } \\
\hline Female (\%) & 49.20 & --- & --- \\
\hline White (\%) & 76.18 & 75.18 & $77.15^{* *}$ \\
\hline Asian (\%) & 7.88 & 6.81 & $8.91 * *$ \\
\hline Black (\%) & 6.79 & $8.13 * *$ & 5.51 \\
\hline Other Race (\%) & 2.01 & $2.18 * *$ & 1.85 \\
\hline Hispanic/Latino (\%) & 7.14 & $7.70^{* *}$ & 6.59 \\
\hline Immigrant (\%) & 13.57 & 11.79 & $15.31^{* *}$ \\
\hline Age & 44.10 & 43.11 & $45.06^{* *}$ \\
\hline Married (\%) & 72.96 & 68.12 & $77.65^{* *}$ \\
\hline Children under 18 in household & 0.79 & 0.74 & $0.84^{* *}$ \\
\hline Difficulty with seeing (\%) & 3.73 & 3.71 & 3.75 \\
\hline Difficulty with hearing (\%) & 2.64 & 1.54 & $3.70^{* *}$ \\
\hline Difficulty with walking (\%) & 1.12 & 1.05 & 1.18 \\
\hline Difficulty with lifting (\%) & 1.36 & $1.65^{* *}$ & 1.09 \\
\hline JD (\%) & 3.40 & 2.89 & $3.89 * *$ \\
\hline MD (\%) & 2.72 & 1.74 & $3.66^{* *}$ \\
\hline MBA (\%) & 3.91 & 2.70 & $5.07 * *$ \\
\hline MA not in business (\%) & 23.25 & $26.43^{* *}$ & 20.16 \\
\hline $\mathrm{PhD}(\%)$ & 3.71 & 2.62 & $4.76^{* *}$ \\
\hline No graduate degree (\%) & 63.02 & $63.62 * *$ & 62.45 \\
\hline \multicolumn{4}{|l|}{ Job Characteristics } \\
\hline Salary (\$) & 71,675 & 55,538 & $87,303^{* *}$ \\
\hline Log(salary) & 10.83 & 10.59 & $11.07^{* *}$ \\
\hline Predicted salary using full sample (\$) & 71,675 & 55,538 & $87,303^{* *}$ \\
\hline Predicted salary using white males (\$) & 78,895 & 67,332 & $90,092 * *$ \\
\hline Health insurance (\%) & 79.91 & 78.16 & $81.60 * *$ \\
\hline Pension plan (\%) & 68.79 & $69.21 *$ & 68.39 \\
\hline Profit-sharing plan (\%) & 24.58 & 21.55 & $27.51 * *$ \\
\hline Paid vacation, sick, or personal days (\%) & 80.18 & 79.96 & 80.40 \\
\hline Log(hours) & 3.67 & 3.58 & $3.75^{* *}$ \\
\hline Tenure (years) & 7.80 & 7.04 & $8.53^{* *}$ \\
\hline Supervisor (\%) & 39.89 & 31.67 & $49.95^{* *}$ \\
\hline 10 or fewer employees (\%) & 15.09 & 12.79 & $17.32 * *$ \\
\hline 11 to 24 employees (\%) & 6.05 & 5.94 & 6.16 \\
\hline 25 to 99 employees (\%) & 10.93 & $11.31^{* *}$ & 10.57 \\
\hline 100 to 499 employees (\%) & 15.49 & $16.39 * *$ & 14.62 \\
\hline 500 to 999 employees (\%) & 7.69 & $9.27 * *$ & 6.17 \\
\hline 1,000 to 4,999 employees (\%) & 15.45 & $16.48^{* *}$ & 14.45 \\
\hline 5,000 to 24,999 employees (\%) & 13.13 & $13.41 *$ & 12.86 \\
\hline 25,000 and more employees (\%) & 16.17 & 14.42 & $17.86^{* *}$ \\
\hline Government employer (\%) & 27.64 & $33.88^{* *}$ & 21.60 \\
\hline
\end{tabular}




\begin{tabular}{|l|c|c|c|}
\hline & All & Female & Male \\
\hline Self-employed (\%) & 19.86 & 16.60 & $23.01^{* *}$ \\
\hline Non-profit employer (\%) & 13.27 & $17.77^{* *}$ & 8.91 \\
\hline For-profit employer (\%) & 38.97 & 31.49 & $46.22^{* *}$ \\
\hline Other employer type (\%) & 0.26 & 0.26 & 0.26 \\
\hline New England (\%) & 6.12 & 5.85 & $6.39^{* *}$ \\
\hline Middle Atlantic (\%) & 14.47 & $14.97^{* *}$ & 13.97 \\
\hline East North Central (\%) & 14.82 & 14.71 & 14.93 \\
\hline West North Central (\%) & 7.43 & $7.74^{* *}$ & 7.12 \\
\hline South Atlantic (\%) & 19.41 & 19.35 & 19.46 \\
\hline East South Central (\%) & 4.67 & 4.70 & 4.64 \\
\hline West South Central (\%) & 9.03 & 8.84 & 9.21 \\
\hline Mountain (\%) & 6.76 & 6.79 & 6.74 \\
\hline Pacific (\%) & 17.30 & 17.04 & 17.54 \\
\hline Management, business, \& financial (\%) & 26.54 & 20.75 & $32.16^{* *}$ \\
\hline Computer, engineering, \& science (\%) & 15.20 & 8.47 & $21.73^{* *}$ \\
\hline Education, legal, \& community service (\%) & 23.31 & $31.36^{* *}$ & 15.52 \\
\hline Arts \& media (\%) & 2.71 & $3.11^{* *}$ & 2.33 \\
\hline Healthcare practitioners \& technical (\%) & 10.32 & $14.31^{* *}$ & 6.46 \\
\hline Service (\%) & 4.62 & 4.40 & $4.83^{*}$ \\
\hline Sales \& related (\%) & 7.39 & 6.42 & $8.32^{* *}$ \\
\hline Office \& administrative support (\%) & 5.66 & $8.95^{* *}$ & 2.48 \\
\hline Blue-collar (\%) & 3.39 & 1.23 & $5.47^{* *}$ \\
\hline Other occupation (\%) & 0.85 & $1.01^{* *}$ & 0.70 \\
\hline Degree closely related (\%) & 56.01 & $58.33^{* *}$ & 53.77 \\
\hline Degree somewhat related (\%) & 23.64 & 20.23 & $26.95^{* *}$ \\
\hline Degree not related (\%) & 20.35 & $21.44^{* *}$ & 19.28 \\
\hline Union percent ${ }^{+}$(\%) & 12.74 & $15.15^{* *}$ & 10.40 \\
\hline Female percent ${ }^{+}$(\%) & 54.61 & $62.54^{* *}$ & 46.92 \\
\hline White percent ${ }^{+}$(\%) & 76.42 & 75.54 & $77.27^{* *}$ \\
\hline Asian percent ${ }^{+}$(\%) & 5.03 & 4.61 & $5.44^{* *}$ \\
\hline Black percent ${ }^{+}$(\%) & 8.58 & $9.53^{* *}$ & 7.65 \\
\hline Other race percent ${ }^{+}$(\%) & 2.25 & $2.32^{* *}$ & 2.17 \\
\hline Hispanic/Latino percent ${ }^{+}$(\%) & 7.72 & $8.00^{* *}$ & 7.46 \\
\hline N & 61,870 & 26,125 & 35,745 \\
\hline & & & \\
\hline
\end{tabular}

Authors' calculations are from the 2010 National Survey of College Graduates in conjunction with CPS. All values are calculated using the NSCG sample weight. ${ }^{+}$signifies that the variable is created from the CPS, and the variable's mean is calculated across individuals in the NSCG. Differences between female and male are tested using the Bonferroni comparison test. * significant at $5 \%$ level; ** significant at $1 \%$ level. 
Appendix 3. Demographics and Job Characteristics Descriptive Statistics by Race or Ethnicity

\begin{tabular}{|c|c|c|c|c|c|}
\hline & White & Asian & Black & $\begin{array}{l}\text { Other } \\
\text { Race }\end{array}$ & $\begin{array}{l}\text { Hispanic/ } \\
\text { Latino }\end{array}$ \\
\hline \multicolumn{6}{|l|}{ Demographics } \\
\hline Female (\%) & 48.55 & $42.53 * *$ & $58.84 * *$ & $53.35 * *$ & $53.09 * *$ \\
\hline Immigrant (\%) & 5.04 & $80.91 * *$ & $15.03 * *$ & $10.72 * *$ & $29.73 * *$ \\
\hline Age & 44.79 & $41.65 * *$ & $43.10 * *$ & $40.55 * *$ & $41.47 * *$ \\
\hline Married (\%) & 75.27 & 75.68 & $53.68 * *$ & $63.48 * *$ & $66.43 * *$ \\
\hline Children under 18 in household & 0.77 & 0.76 & $0.91 * *$ & 0.77 & $0.90 * *$ \\
\hline Difficulty with seeing (\%) & 3.37 & 3.47 & $5.42 * *$ & 3.26 & $6.34 * *$ \\
\hline Difficulty with hearing (\%) & 2.96 & $1.60 * *$ & $1.11^{* *}$ & 2.45 & $1.84 * *$ \\
\hline Difficulty with walking (\%) & 1.05 & 0.77 & $2.36 * *$ & $2.73 * *$ & $0.63 *$ \\
\hline Difficulty with lifting (\%) & 1.12 & $1.55 * *$ & $3.00 * *$ & $3.63 * *$ & $1.60 *$ \\
\hline JD (\%) & 3.77 & $1.47 * *$ & $2.07 * *$ & 3.88 & $2.66^{* *}$ \\
\hline MD (\%) & 2.55 & $5.32 * *$ & $1.58 * *$ & 2.82 & 2.71 \\
\hline MBA (\%) & 3.76 & 4.11 & $6.32 * *$ & 2.74 & 3.26 \\
\hline MA not in business (\%) & 23.39 & 24.68 & 24.46 & $18.02 * *$ & $20.46 * *$ \\
\hline $\mathrm{PhD}(\%)$ & 3.53 & $7.61 * *$ & $2.75 *$ & 2.38 & $2.65 * *$ \\
\hline No graduate degree (\%) & 63.01 & 56.82 & 62.81 & 70.15 & 68.25 \\
\hline \multicolumn{6}{|l|}{ Job Characteristics } \\
\hline Salary (\$) & 72,917 & $77,826 * *$ & $63,423 * *$ & $65,833 * *$ & $61,127 * *$ \\
\hline Log(salary) & 10.84 & $10.97 * *$ & $10.70 * *$ & 10.85 & $10.70 * *$ \\
\hline Predicted salary full sample (\$) & 72,917 & $77,826 * *$ & $63,423 * *$ & $65,833 * *$ & $61,127 * *$ \\
\hline Predicted salary white males (\$) & 78,248 & $92,540 * *$ & $74,180 * *$ & $73,136 * *$ & 76,858 \\
\hline Health insurance (\%) & 79.12 & $80.39 *$ & $85.47 * *$ & $82.89 * *$ & $81.69 * *$ \\
\hline Pension plan (\%) & 68.70 & $63.64 * *$ & $75.93 * *$ & 67.93 & 68.95 \\
\hline Profit-sharing plan (\%) & 24.02 & $25.75 * *$ & $28.45 * *$ & $19.01 * *$ & $27.22 * *$ \\
\hline $\begin{array}{l}\text { Paid vacation, sick, or personal days } \\
\text { (\%) }\end{array}$ & 79.49 & 80.29 & $84.12 * *$ & $85.52 * *$ & $82.25 * *$ \\
\hline Log(hours) & 3.66 & $3.68 *$ & 3.66 & 3.69 & 3.67 \\
\hline Tenure (years) & 8.16 & $6.46 * *$ & $6.67 * *$ & $6.63 * *$ & $6.86 * *$ \\
\hline Supervisor (\%) & 40.92 & $37.02 * *$ & $37.98 * *$ & 37.97 & $34.45 * *$ \\
\hline 10 or fewer employees (\%) & 16.05 & $13.82 * *$ & $8.40 * *$ & 15.98 & $12.34 * *$ \\
\hline 11 to 24 employees (\%) & 6.30 & 5.95 & $2.99 * *$ & $8.45 * *$ & 5.79 \\
\hline 25 to 99 employees (\%) & 11.40 & $9.73^{* *}$ & $8.11^{* *}$ & 10.02 & 10.25 \\
\hline 100 to 499 employees (\%) & 15.99 & $12.53 * *$ & 17.33 & 16.96 & $11.32 * *$ \\
\hline 500 to 999 employees (\%) & 7.74 & 7.12 & 8.00 & $4.66 * *$ & 8.34 \\
\hline 1,000 to 4,999 employees (\%) & 15.22 & 15.36 & $16.74 *$ & 13.66 & $17.24 * *$ \\
\hline 5,000 to 24,999 employees (\%) & 12.70 & 13.51 & $14.36 * *$ & 12.68 & $16.18 * *$ \\
\hline 25,000 and more employees (\%) & 14.60 & $21.97 * *$ & $24.06 * *$ & $17.59 * *$ & $18.54 * *$ \\
\hline Government employer (\%) & 26.74 & $19.42 * *$ & $39.39 * *$ & $31.28 * *$ & $34.02 * *$ \\
\hline Self-employed (\%) & 20.57 & 21.16 & $13.79 * *$ & $16.42 * *$ & $17.56^{* *}$ \\
\hline Non-profit employer (\%) & 13.61 & $10.55 * *$ & 14.31 & 15.38 & $11.04^{* *}$ \\
\hline
\end{tabular}




\begin{tabular}{|c|c|c|c|c|c|}
\hline & White & Asian & Black & $\begin{array}{l}\text { Other } \\
\text { Race }\end{array}$ & $\begin{array}{l}\text { Hispanic/ } \\
\text { Latino }\end{array}$ \\
\hline For-profit employer (\%) & 38.96 & $48.25^{* *}$ & $32.06^{* *}$ & 35.93 & $36.30^{* *}$ \\
\hline Other employer type (\%) & 0.11 & $0.62^{* *}$ & $0.45^{* *}$ & $1.00^{* *}$ & $1.07 * *$ \\
\hline New England (\%) & 6.98 & $4.30 * *$ & $2.80 * *$ & $3.66 * *$ & $2.79 * *$ \\
\hline Middle Atlantic (\%) & 14.63 & $17.65^{* *}$ & $14.77^{* *}$ & 10.67 & $9.94 * *$ \\
\hline East North Central (\%) & 16.53 & $10.63^{* *}$ & $11.32^{* *}$ & $10.59 * *$ & $5.71^{* *}$ \\
\hline West North Central (\%) & 8.82 & $2.61^{* *}$ & $3.47 * *$ & $5.10^{* *}$ & $2.26 * *$ \\
\hline South Atlantic (\%) & 18.45 & $13.67 * *$ & $37.49 * *$ & $23.15^{* *}$ & 17.66 \\
\hline East South Central (\%) & 5.08 & $1.55^{* *}$ & $8.41^{* *}$ & $1.62 * *$ & $1.06^{* *}$ \\
\hline West South Central (\%) & 8.18 & 7.91 & $10.69 * *$ & $11.72^{* *}$ & $16.99 * *$ \\
\hline Mountain (\%) & 7.55 & $3.07 * *$ & $1.80^{* *}$ & $5.52 * *$ & 7.54 \\
\hline Pacific (\%) & 13.77 & $38.61^{* *}$ & $9.26 * *$ & $27.96 * *$ & $36.05 * *$ \\
\hline $\begin{array}{l}\text { Management, business, \& financial } \\
\text { (\%) }\end{array}$ & 27.12 & $22.33^{* *}$ & 26.37 & 28.14 & $24.78^{* *}$ \\
\hline $\begin{array}{l}\text { Computer, engineering, \& science } \\
\text { (\%) }\end{array}$ & 14.06 & $33.87^{* *}$ & $10.96^{* *}$ & 13.56 & $11.34 * *$ \\
\hline $\begin{array}{l}\text { Education, legal, \& community } \\
\text { service (\%) }\end{array}$ & 24.18 & $8.76^{* *}$ & $27.76^{* *}$ & 22.14 & $26.20 * *$ \\
\hline Arts \& media (\%) & 2.97 & $1.14^{* *}$ & $2.11^{* *}$ & 2.22 & 2.37 \\
\hline $\begin{array}{l}\text { Healthcare practitioners \& technical } \\
\text { (\%) }\end{array}$ & 9.91 & $15.99 * *$ & 9.30 & 9.86 & 9.57 \\
\hline Service (\%) & 4.37 & 3.75 & $6.28 * *$ & 4.98 & $6.58 * *$ \\
\hline Sales \& related (\%) & 7.78 & $5.52 * *$ & $4.97 * *$ & 6.71 & 7.77 \\
\hline Office \& administrative support (\%) & 5.19 & $6.36 * *$ & $8.05^{* *}$ & $9.45 * *$ & $6.56 * *$ \\
\hline Blue-collar (\%) & 3.50 & $1.81^{* *}$ & 3.34 & 2.53 & 4.16 \\
\hline Other occupation (\%) & 0.92 & $0.46^{* *}$ & 0.85 & 0.41 & 0.66 \\
\hline Degree closely relate & 55.79 & $59.15^{* *}$ & $53.08 * *$ & 55.89 & $57.74 *$ \\
\hline Degree somewhat related (\%) & 23.76 & 23.41 & 23.82 & 23.09 & 22.60 \\
\hline Degree not related (\%) & 20.45 & $17.44^{* *}$ & $23.10^{* *}$ & 21.01 & 19.66 \\
\hline Union percent $^{+}(\%)$ & 12.89 & $9.46^{* *}$ & $13.74^{* *}$ & 12.03* & $13.91^{* *}$ \\
\hline Female percent $^{+}(\%)$ & 54.75 & $49.92 * *$ & $57.06 * *$ & 55.17 & $55.73 * *$ \\
\hline White percent ${ }^{+}(\%)$ & 76.58 & $75.78^{* *}$ & $75.57^{* *}$ & 76.54 & $76.21^{* *}$ \\
\hline Asian percent $^{+}(\%)$ & 4.93 & $6.56^{* *}$ & $4.77 * *$ & 4.86 & $4.72 * *$ \\
\hline Black percent $^{+}(\%)$ & 8.51 & $8.28 * *$ & $9.37 * *$ & 8.55 & $8.82 * *$ \\
\hline Other race percent ${ }^{+}(\%$ & 2.25 & $2.16^{* *}$ & $2.32 * *$ & 2.25 & $2.29 * *$ \\
\hline o percent ${ }^{+}(\%)$ & 7.73 & $7.21 * *$ & $7.96 * *$ & 7.79 & $7.96 * *$ \\
\hline $\mathrm{N}$ & 38,149 & 10,119 & 5,629 & 1,756 & 6,217 \\
\hline
\end{tabular}

Authors' calculations are from the 2010 National Survey of College Graduates in conjunction with CPS. All values are calculated using the NSCG sample weight. ${ }^{+}$signifies that the variable is created from the CPS, and the variable's mean is calculated across individuals in the NSCG. Differences between white and another race or ethnicity are tested using the Bonferroni comparison test. * significant at $5 \%$ level; ** significant at $1 \%$ level. 